\title{
Effects of Selected Plant Growth Regulators on Bread Wheat Spike Development
}

\author{
Ali Rasaei ${ }^{1}$, Saeid Jalali Honarmand ${ }^{1}$, Mohsen Saeidi ${ }^{1}$, Mohammad-Eghbal Ghobadi ${ }^{1} \&$ Shahrokh Khanizadeh $^{2}$ \\ ${ }^{1}$ Department of Agronomy and Plant Breeding, Campus of Agriculture and Natural Resources, Razi University, \\ Kermanshah, Iran \\ ${ }^{2}$ Ottawa Research and Development Centre, Agriculture and Agri-Food Canada, Canada \\ Correspondence: Shahrokh Khanizadeh, Ottawa Research and Development Centre, Agriculture and Agri-Food \\ Canada, Canada. E-mail: shahrokh.khanizadeh@agr.gc.ca
}

Received: August 25, 2016 Accepted: September 27, 2016 Online Published: March 31, 2017

doi:10.5539/sar.v6n2p115 URL: https://doi.org/10.5539/sar.v6n2p115

\begin{abstract}
Although the grain yield of wheat is finally determined after anthesis, the yield potential is largely dependent on early growth and development. At the specific stage from double ridge to terminal spikelet, spikelet initiation occurs and can affect the number of grains per spike and the grain yield. A factorial experiment using a randomized complete blocks design with six replicates was used to study the effect of three growth regulators (3-indoleacetic acid [IAA], gibberellic acid $\left[\mathrm{GA}_{3}\right]$, and 6-benzylaminopurine [6-BAP]) on two bread wheat (Triticum aestivum L.) cultivars (Rijaw and Azar-2), at the Campus of Agriculture and Natural Resources of Razi University, in Kermanshah, Iran, during the 2013-2014 and 2014-2015 cropping seasons. The effect of the hormones was not significant for spikelet initiation number or spikelet initiation rate based on days and growing degree days (GDDs), but apical meristem length and rate of elongation of the apical meristem were affected by exogenous application of hormones in both years. The Rijaw genotype was better than Azar-2 with respect to apical meristem traits. As well, biplot diagrams showed that the treatment combination 6-BAP $\times$ Rijaw was the best in terms of shoot apex length and rate of shoot apex elongation and that the treatment combination $\mathrm{GA}_{3} \times \mathrm{Rijaw}$ was the best in terms of spikelet number and rate of spikelet initiation. It is concluded that each hormone can improve specific apical meristem characteristics and that the rate of each hormone's effect depends on the plant's genetic feature and on the environmental conditions.
\end{abstract}

Keywords: apical meristem, plant hormone, spikelet, wheat

\section{Introduction}

Bread wheat (Triticum aestivum L.) is a main food crop and a strategic cereal crop around the world. Because wheat can be used directly, for thousands of years it has provided most of the daily food for the world's population: today, wheat provides $20 \%$ of the consumed calories in the world and more than $40 \%$ to $45 \%$ of daily calories and $50 \%$ of daily protein for people in Iran (Iran-Nejad \& Shahbaziyan, 2005; Kalantari et al., 2005; Braun et al., 2010). Thanks to its high capacity for adaptation to different environmental climates, wheat has a wide distribution in the world (Cakmak, 2008; Amiri et al., 2015). In recent decades, increasing food demand and water deficit have created a challenge in terms of food security around the world (Zwart \& Bastiaannsen, 2004; Reynolds et al., 2011). Although great successes have been achieved in improving the yields of crops, especially wheat, through crop breeding methods, we have a long way to go before we reach the theoretical wheat yield potential ( $20 \mathrm{t} / \mathrm{ha}$ ) that is estimated by cereal physiologists (Evans, 1993). Studies show that gaining adequate knowledge of the formation and physiology of crop yield, being able to distinguish changes created by different factors in the life cycle of the crop, and identifying the relationship between the impacts of these factors on the formation of yield components can be effective in making genetic achievements to improve grain yield (Pedró et al., 2012; Reynolds et al., 2012).

The final grain yield of wheat consists of three main components, namely, the number of spikes per ground unit, the number of grains per spike, and thousand grain weight, and each component is shaped during a specific stage of wheat growth and development (Figure 1) (Itoh et al., 1998; Acreche \& Slafer, 2006). However, there are two main methods for classifying the different growth stages of wheat: morphological classification and physiological classification. The morphological characteristics of wheat are presented using the Zadoks scale 
(Zadoks et al., 1974), and the physiological development of the wheat apical meristem is showed on a quantitative scale (Waddington et al., 1983), on which each code represents a particular stage of development of the wheat spike (apical meristem). [Figure 1] [Figure 2]

Studying the developmental stages of wheat based on morphological characteristics in order to assess the plant requirements at different growth stages is important, but these divisions do not provide physiologists with accurate information to distinguish the effects of wheat management and environmental factors on spike formation and grain size, which will later determine the grain yield.

Based on developmental classification, the appearance of a double ridge on the shoot apex is an indication of the transition of wheat from the vegetative phase to the reproductive phase (Figure 2), because spikelet and floret differentiation starts during this period (double ridge to terminal spikelet). In other words, the terminal spikelet marks the end of spikelet primordia initiation (grain set potential) (Figure 1) (Pask et al., 2012), and thus the potential grain yield is largely dependent on the pre-anthesis events (Li et al., 1999; Wang et al., 2001). One to two thirds of the florets that form before the terminal spikelet phase will be aborted around the booting stage (Bancal, 2009). Finally, grain weight will be formed after the anthesis phase until physiological maturity (grain filling).

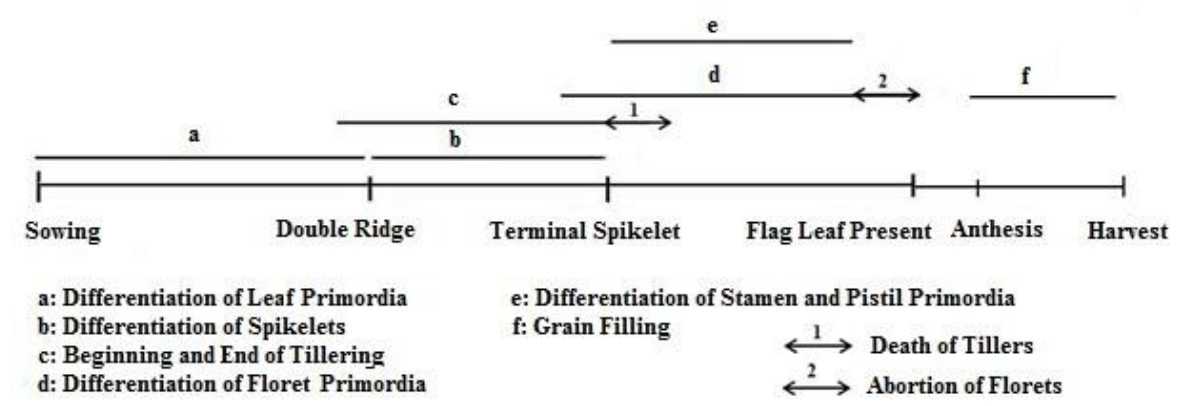

Figure 1. Formation stages of different components of wheat yield from sowing to harvest (adapted from McMaster et al., 1992 with minor changes)

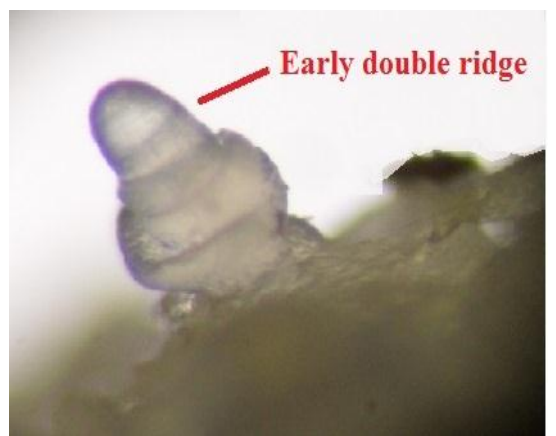

Figure 2. Early Double ridge initiation. The photo was provided by the authors and was taken during the experiment

Plant hormones (plant growth regulators) are the most important internal factors for the regulation of plant growth in response to environmental and genetic factors. For example, water deficit is the main factor for the significant accumulation of abscisic acid in relation to corn kernel abortion (Ober \& Sharp, 1994). Water deficit also increases abscisic acid levels in leaves and spikelets of wheat, which reduces the number of seeds (Wilkinson \& Davies, 2002). Studies have shown that plant hormones could regulate the partitioning and translocation of photoassimilates during grain filling (Ahmadi \& Baker, 1999). Both 3-indoleacetic acid (IAA) and cytokinins have been shown to play an important role in the transportation of assimilates to wheat spikes (Darussalam et al., 1998; Lejeune et al., 1998). As well, cytokinins are required for cell division during the early phase of grain filling (Yang et al., 2000). The exogenous application of abscisic acid was found to reduce chlorophyll in flag leaves, whereas remobilization and rate of grain filling were enhanced by increasing abscisic acid (Yang et al., 2003b/ 2006). The application of chlormequat and ethephon was found to increase wheat grain yield, because these substances reduced the plant height and improved the partitioning of dry matter into the 
spikes (Shekoofa \& Emam, 2008).

However, most of the previous studies concerned the effects of plant hormones on the wheat yield formation processes that occur after anthesis. Investigating the relationships between hormones and their roles in the formation of wheat yield, especially at the early stages of spike physiological development, can be important. Thus, the objective of this study was to determine the effects of the exogenous application of plant growth regulators at a specific pre-anthesis stage, namely, the period from double ridge to terminal spikelet, on apical meristem characteristics in two wheat genotypes.

\section{Material and Methods}

\subsection{Study location}

The study was conducted for two cropping seasons in the experimental field at the Campus of Agriculture and Natural Resources of Razi University, in Kermanshah, Iran ( $34^{\circ} 21^{\prime} \mathrm{N} ; 47^{\circ} 9^{\prime} \mathrm{E}$; $319 \mathrm{~m}$ AMSL). This location is in a semi-arid zone. The soil texture was clay with a $\mathrm{pH}$ of 7.8. The rates of $\mathrm{N}, \mathrm{P}_{2} \mathrm{O}_{5}$, and $\mathrm{K}_{2} \mathrm{O}$ in the soil before the experiment were $0.012 \%, 8 \mathrm{ppm}$, and $400 \mathrm{ppm}$, respectively. Weather characteristics, including monthly average temperatures $\left({ }^{\circ} \mathrm{C}\right)$ and total rainfall $(\mathrm{mm})$, for both years of the experiment are shown in Figure 3.

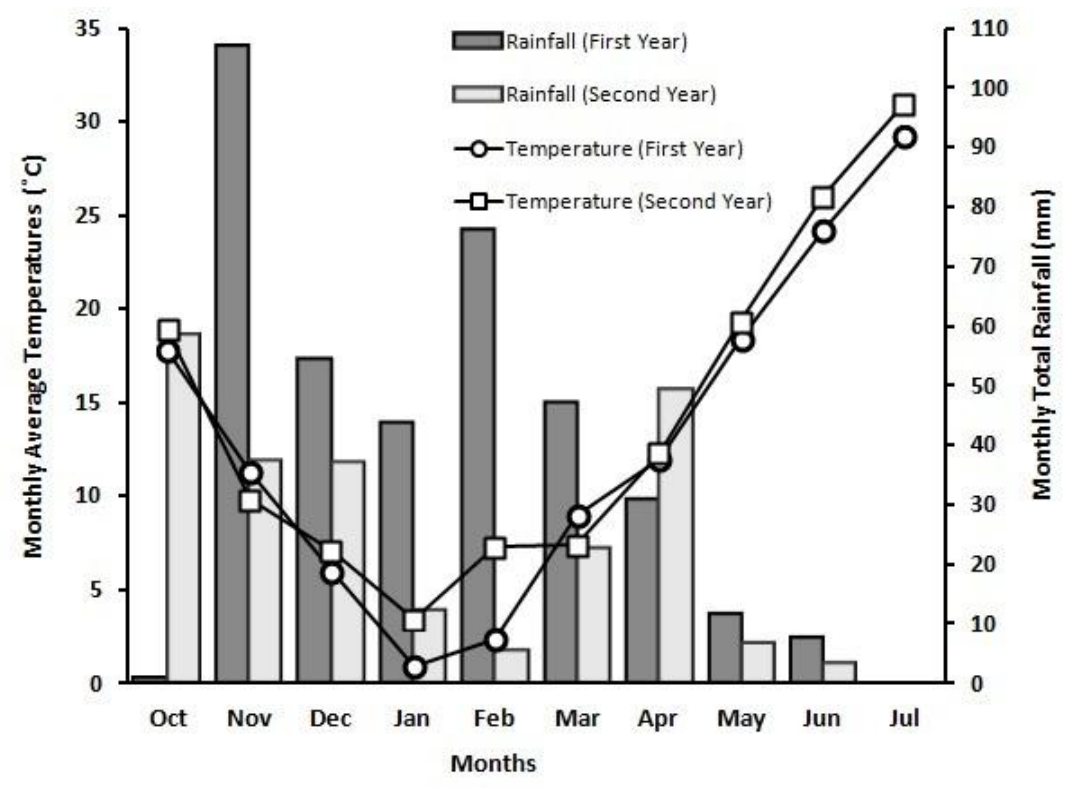

Figure 3. Monthly average temperatures $\left({ }^{\circ} \mathrm{C}\right)$ and total rainfall $(\mathrm{mm})$ in the two crop seasons (2013-2014 and 2014-2015) of the experiment

\subsection{Experimental Design}

Each experiment was carried out as factorial based on a randomized complete block design with six replications in the 2013-2014 and 2014-2015 cropping seasons. The factors were (i) exogenous application of different plant growth regulators, namely, IAA, gibberellic acid $\left(\mathrm{GA}_{3}\right)$, and 6-benzylaminopurine (6-BAP), and distilled water as the control at a specific physiological development stage of the apical meristem of wheat, namely, double ridge to terminal spikelet, and (ii) two dry-land wheat genotypes (cv. Rijaw and cv. Azar-2), which have optimum and low grain yield potential in Kermanshah province, respectively. The cultivar Rijaw is a newly released rain-fed cultivar. The hormone concentration applied for each hormone was $50 \mu \mathrm{M}$, in accordance with previous studies (Yang et al., 2002/ 2003a). Each plot contained six planting rows with $2.5 \mathrm{~m}$ length. The space between planting rows was $25 \mathrm{~cm}$, and planting density was 300 seeds $/ \mathrm{m}^{2}$. The distance between the plots was $50 \mathrm{~cm}$. Sowing was performed manually. At the hormone application step, to ensure the absorption of the plant growth regulators, foliar application was done on three consecutive days after sunset (to prevent degradation of the plant growth regulators by sunlight).

\subsection{Apical Meristem Measurement}

Three main shoots from each plot were measured after the initiation of the double ridge (Figure 2). The developed spikelets were investigated using a quantitative scale (Waddington et al., 1983). The main shoot apex 
was dissected to determine the apex length and the number of spikelet primordia present on the apex. The number of spikelet buds and the apex length were measured using a binocular microscope at $40 \times$ magnification (Figure 2). The double unit of leaf primordium and spikelet bud was counted as one (Kirby, 1974). The rate of apex elongation $(\alpha)$ and the rate of spikelet initiation $(\beta)$ were expressed per day and growing degree day (GDD). These parameters were calculated by dividing the number of spikelets $(S)$ and length of the apex $(L$, in $\mathrm{mm})$ by the duration between double ridge $\left(D_{1}\right)$ and terminal spikelet $\left(D_{2}\right)$, on the basis of days and GDDs (Table 1) (Kafi, 2001), as follows:

$$
\begin{aligned}
& \beta=S /\left(D_{2}-D_{1}\right) \\
& \alpha=L /\left(D_{2}-D_{1}\right) \rightarrow(\mathrm{mm} / \text { day }),(\mathrm{mm} / \mathrm{GDD})
\end{aligned}
$$

Table 1. Duration of the period from double ridge to terminal spikelet based on days and growing degree days (GDDs)

\begin{tabular}{cccc}
\hline Year & Genotype & $\begin{array}{c}\text { Double ridge to terminal } \\
\text { spikelet based on days }\end{array}$ & $\begin{array}{c}\text { Double ridge to terminal spikelet } \\
\text { based on GDDs }\left({ }^{\circ} \mathrm{Cd}\right)\end{array}$ \\
\hline 2014 & Rijaw & 14 & 68.5 \\
2014 & Azar-2 & 16 & 92.0 \\
2015 & Rijaw & 10 & 67.4 \\
2015 & Azar-2 & 19 & 89.8 \\
\hline
\end{tabular}

\subsection{Statistical Analysis}

The normality test of data, data analysis, mean comparisons, and diagram preparation were performed with the SPSS, SAS 9.1, GGEbiplot, and Excel software packages.

\section{Results}

Based on our data, the application of different exogenous plant hormones during the stage from double ridge to terminal spikelet had no significant effect on spikelet number and rate of spikelet initiation (based on days and GDDs) in both years of the experiment, whereas apical meristem length and rate of apical meristem elongation (based on days and GDDs) were affected by hormone application (Tables 2 and 3). The genotypes showed significant differences in all the apical meristem traits in both years $(P=0.01)$ (Tables 2 and 3). However, the interaction effects between genotypes and plant hormones were different in both years. The interaction effect of genotype $\times$ hormone in each year was significant on spikelet number, apical meristem length, and rate of apical meristem elongation (based on days) but was not significant on rate of spikelet initiation (based on GDDs), whereas that interaction had a significantly effect on rate of spikelet initiation (based on days) in the first year of the experiment only and on rate of apical meristem elongation (based on GDDs) in the second year of the experiment only (Tables 2 and 3). As shown in Figure 4, the Rijaw genotype was superior to Azar-2 for all the shoot apex traits with the different hormones used. There was a significant difference in the traits between the crops to which plant hormones were applied and the controls (to which distilled water was applied). In both years of the experiment, $\mathrm{GA}_{3}$ and 6-BAP led to the initiation of more spikelets on the apical meristem, but this effect was observed only in the Rijaw genotype (Figures $4 \mathrm{a}$ and 5a). The highest spikelet initiation number was obtained by exogenous application of $\mathrm{GA}_{3}$ and 6-BAP, with 19.3 and 18.6 spikelets (in the first year) and 18.1 and 17.8 spikelets (in the second year) per apical meristem, respectively (Figures $4 \mathrm{a}$ and $5 \mathrm{a}$ ). In both years of the experiment, apical meristem length and rate of elongation of the apical meristem (based on days) in the Rijaw genotype were highest when the wheat plants were treated with 6-BAP (Figures 4b, c, and 5b, c), As well, the highest and lowest measured apical meristem lengths at the terminal spikelet stage were associated with the application of 6-BAP to the Rijaw genotype (4.2 and $3.7 \mathrm{~mm}$ in the first and second years) and the application of distilled water (control) to the Azar-2 genotype (3.2 and $3.3 \mathrm{~mm}$ in the first and second years), respectively (Figures $4 \mathrm{~b}$ and $5 \mathrm{~b}$ ). Moreover, 6-BAP promoted higher apical meristem elongation rates based on days (in both years) in the Rijaw genotype, with 0.300 and $0.377 \mathrm{~mm} / \mathrm{d}$ in the first and second years, respectively (Figures $4 \mathrm{c}$ and $5 \mathrm{c}$ ). However, for rate of spikelet initiation (based on days) in the first year of the experiment, $\mathrm{GA}_{3}$ was higher (Figure 4d), and for apical meristem elongation rate (based on GDDs) in the second year of the experiment, 6-BAP was higher, with $0.055 \mathrm{~mm} / \mathrm{GDD}$ (Figure 5d); as with the previous two traits, the effects of these hormones were greater in Rijaw than in Azar-2. [Table 1] [Table 2] [Table 3] [Figure 4] [Figure 5] 
Table 2. The ANOVA table for the shoot apex traits of two wheat genotypes (Rijaw and Azar-2) treated with different plant hormones (3-indoleacetic acid, gibberellic acid, and 6-benzylaminopurine) from double ridge to terminal spikelet stage in the first year of the experiment

\begin{tabular}{|c|c|c|c|c|c|c|c|}
\hline \multirow[b]{2}{*}{$\begin{array}{c}\text { Sources of } \\
\text { variation }\end{array}$} & \multicolumn{7}{|c|}{$F$} \\
\hline & $d f$ & $\begin{array}{l}\text { Spikelet } \\
\text { number }\end{array}$ & $\begin{array}{c}\text { Rate of } \\
\text { spikelet } \\
\text { initiation } \\
\text { (days) }\end{array}$ & $\begin{array}{c}\text { Rate of } \\
\text { spikelet } \\
\text { initiation } \\
\text { (GDDs) }\end{array}$ & $\begin{array}{c}\text { Apical } \\
\text { meristem } \\
\text { length }\end{array}$ & $\begin{array}{l}\text { Rate of apical } \\
\text { meristem } \\
\text { elongation } \\
\text { (days) }\end{array}$ & $\begin{array}{c}\text { Rate of apical } \\
\text { meristem } \\
\text { elongation } \\
\text { (GDDs) }\end{array}$ \\
\hline Replication & 5 & $70.4 * *$ & $63.9^{*}$ & $52.4 * *$ & $288.5^{* * *}$ & $269.7 * *$ & $154.6^{* *}$ \\
\hline Genotype (G) & 1 & $114.0^{* *}$ & $519.7 * *$ & $1170.3^{* *}$ & $2843.8^{* *}$ & $10269.3 * *$ & $12955.0^{* *}$ \\
\hline Hormone $(\mathrm{Hr})$ & 3 & $1.4 \mathrm{~ns}$ & $1.5 \mathrm{~ns}$ & $1.3 \mathrm{~ns}$ & $253.1 * *$ & $268.2^{* *}$ & $134.0 * *$ \\
\hline $\mathrm{G} \times \mathrm{Hr}$ & 3 & $3.3 *$ & $3.0^{*}$ & $2.6 \mathrm{~ns}$ & $7.0 * *$ & $3.8^{*}$ & $2.6 \mathrm{~ns}$ \\
\hline CV\% & - & 3.44 & 3.62 & 4.00 & 1.00 & 0.96 & 1.33 \\
\hline
\end{tabular}

$* P \leq 0.05 ; * * P \leq 0.01 ;$ ns, not significant.

Table 3. The ANOVA table for the shoot apex traits of two wheat genotypes (Rijaw and Azar-2) treated with different plant hormones (3-indoleacetic acid, gibberellic acid, and 6-benzylaminopurine) during the period from double ridge to terminal spikelet stage in the second year of the experiment

\begin{tabular}{|c|c|c|c|c|c|c|c|}
\hline \multirow[b]{2}{*}{$\begin{array}{c}\text { Sources of } \\
\text { variation }\end{array}$} & \multicolumn{7}{|c|}{$F$} \\
\hline & $d f$ & $\begin{array}{l}\text { Spikelet } \\
\text { number }\end{array}$ & $\begin{array}{l}\text { Rate of spikelet } \\
\text { initiation (days) }\end{array}$ & $\begin{array}{l}\text { Rate of spikelet } \\
\text { initiation } \\
\text { (GDDs) }\end{array}$ & $\begin{array}{l}\text { Apical } \\
\text { meristem } \\
\text { length }\end{array}$ & $\begin{array}{c}\text { Rate of apical } \\
\text { meristem elongation } \\
\text { (days) }\end{array}$ & $\begin{array}{c}\text { Rate of apical } \\
\text { meristem elongation } \\
\text { (GDDs) }\end{array}$ \\
\hline Replication & 5 & $79.0 * *$ & $35.2 * *$ & $62.9^{* *}$ & $22.9 * *$ & $73.5^{* * *}$ & $239.8 * *$ \\
\hline Genotype (G) & 1 & $111.4 * *$ & $8183.8 * *$ & $3696.3 * *$ & $1194.7 * *$ & $257758.0^{* * *}$ & $225297.0 * *$ \\
\hline Hormone(Hr) & 3 & $1.3 \mathrm{~ns}$ & $0.9 \mathrm{~ns}$ & $1.4 \mathrm{~ns}$ & $107.3 * *$ & $266.2 * *$ & $890.2 * *$ \\
\hline $\mathrm{G} \times \mathrm{Hr}$ & 3 & $3.0 *$ & $1.6 \mathrm{~ns}$ & $2.6 \mathrm{~ns}$ & $3.1^{*}$ & $17.8^{* * *}$ & $14.9 * *$ \\
\hline$C V \%$ & - & 1.70 & 2.55 & 1.90 & 0.75 & 0.46 & 0.26 \\
\hline
\end{tabular}

$* P \leq 0.05 ; * * P \leq 0.01 ;$ ns, not significant.
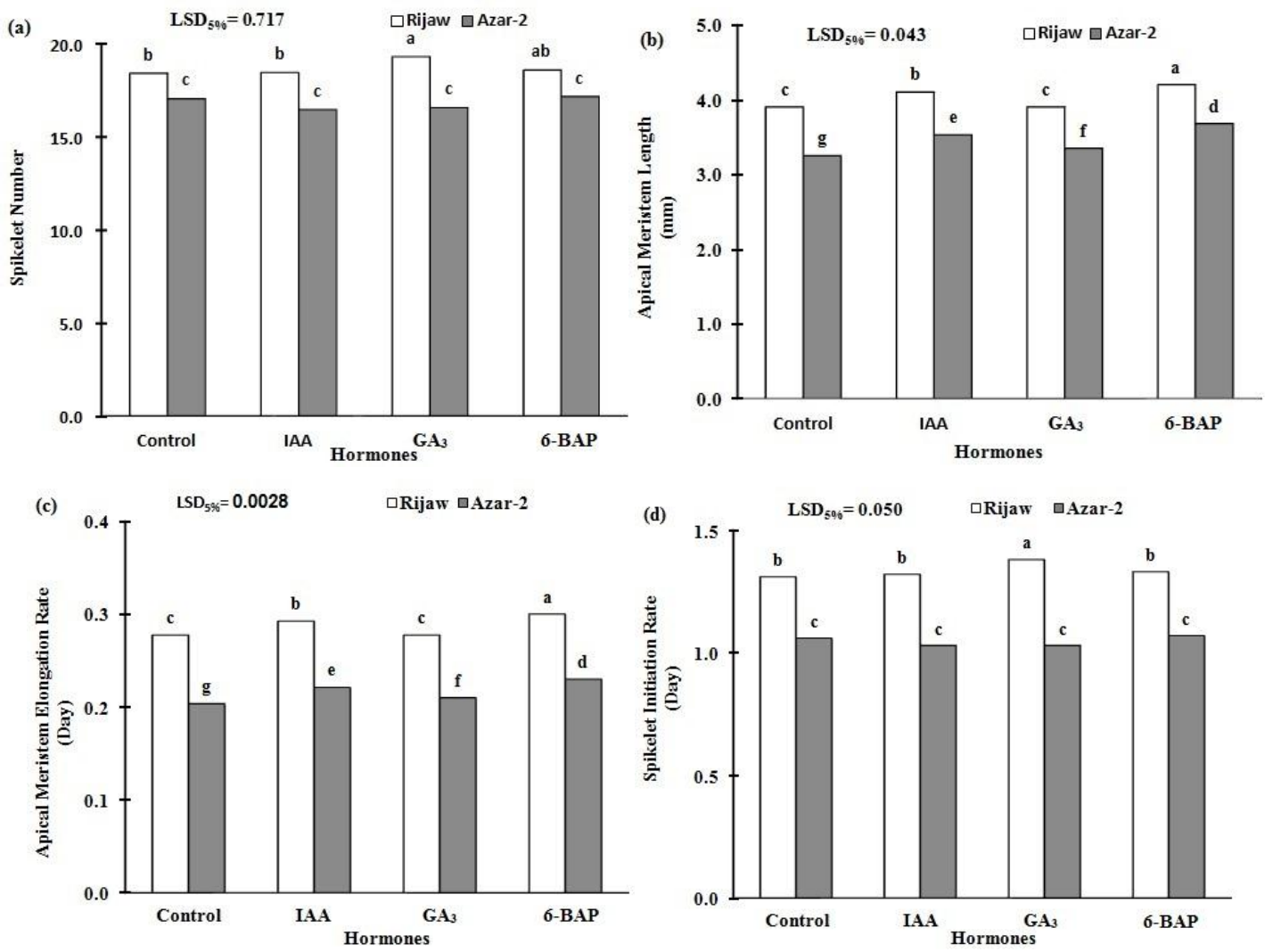

Figure 4. Interaction effects between exogenous applications of different plant growth regulators (3-indoleacetic acid [IAA], gibberellic acid [ $\mathrm{GA}_{3}$ ], and 6-benzylaminopurine [6-BAP]) and two wheat genotypes (Rijaw and

Azar-2) on shoot apex traits during the stage from double ridge to terminal spikelet in the first year of the experiment. Means with the same letter are not significantly different 

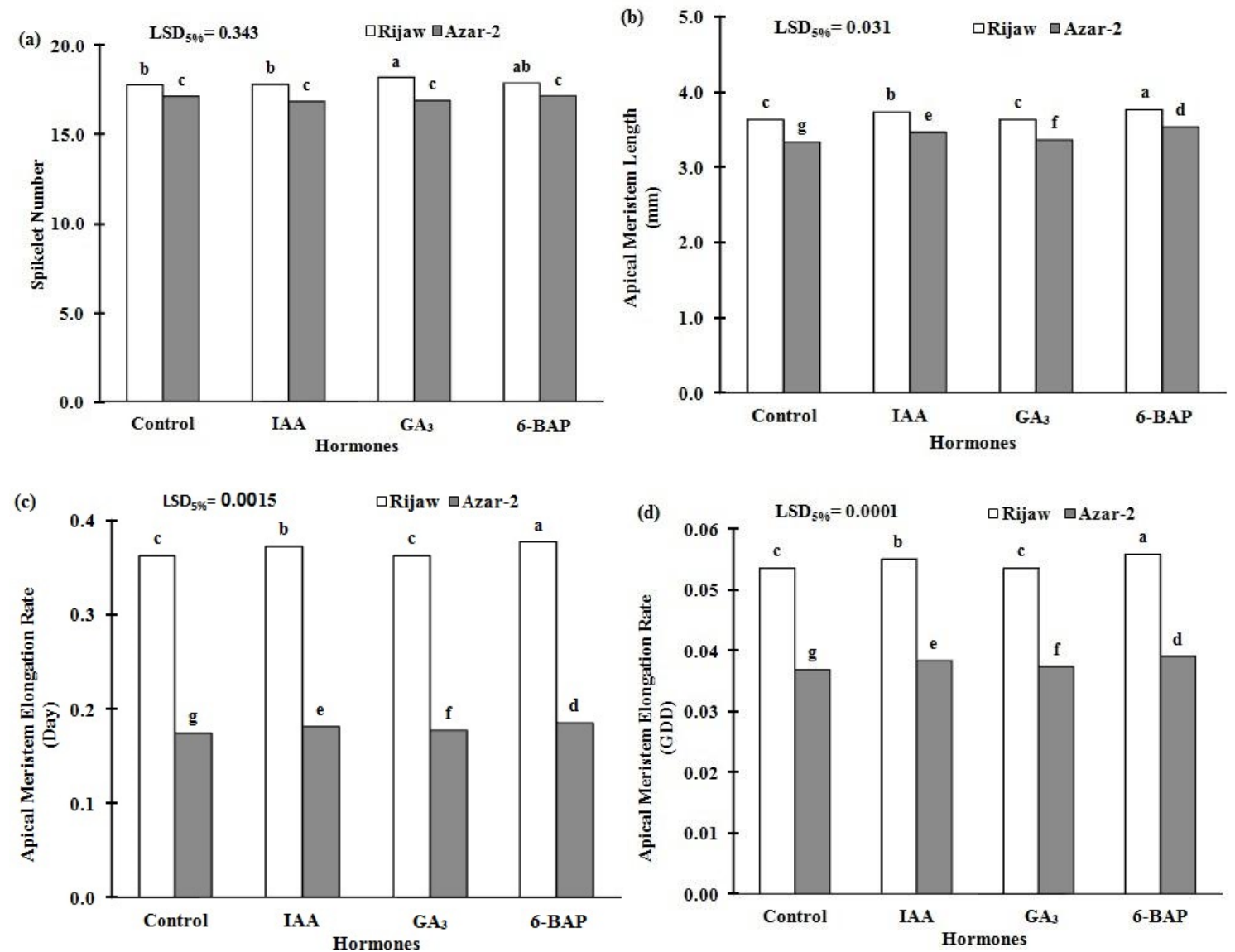

Figure 5. Interaction effects between exogenous applications of different plant growth regulators (3-indoleacetic acid [IAA], gibberellic acid [ $\mathrm{GA}_{3}$ ], and 6-benzylaminopurine [6-BAP]) and two wheat genotypes (Rijaw and Azar-2) on shoot apex traits during the stage from double ridge to terminal spikelet in the second year of the experiment. Means with the same letter are not significantly different

\section{Discussion}

The period from double ridge to terminal spikelet is an important stage in grain set of wheat spikes. When the wheat apical meristem enters the double ridge stage, spikelet initiation starts and will continue until the terminal spikelet stage. The number of initiated spikelets per spike, spikelet initiation rate, and the length of the shoot apex from double ridge to terminal spikelet are important, and the final grain yield will be higher if those traits are higher. Thus, during the period from double ridge to terminal spikelet, two important traits, namely, number of spikelets per spike and number of florets per spikelet, are shaped, and they have an effect on the final grains number, consequently, the grain yield can be increased (Itoh et al., 1998), because there is a close positive relationship between the grains number per spike and the final grain yield (Duggan et al., 2000; Brancourt-Hulmel et al., 2003; González et al., 2003). Also, the relationship between the spikelet and the spike can determine the yield production capacity (Duggan \& Fowler, 2006). According to our results, the exogenous application of different plant hormones increased grain yield in comparison with the controls, and thus the wheat treated with 6-BAP was significantly different from the controls and had improved grain yield and grain number (Table 4). The increasing ratios for grain yield were higher in the second year even though the grain yields were lower than they were in the first year (Table 4). This result may have been related to differences in rainfall amount and temperature in February (time of double ridge appearance) between the first and second years (Figure 3), because the rainfall amount was much lower and the temperature was higher in the second year of the experiment than in the first year, and such differences would influence which hormones were more effective on the final grain yield. In other words, the grain yield of the control plots decreased more, so that the increasing ratios were high for the wheat treated with plant hormones (Table 4). However, this relationship was not true for the number of grains per spike, because the number of initiated spikelets was lower in the second year than in the first year, leading to a decrease in grain number. Although previous studies reported that an acceleration in apical 
meristem development led to a reduced spikelet number in each shoot apex and thus lower yield potential (Maas \& Grieve, 1990; Munns \& Rawson, 1999; Kafi, 2001), in the present experiment the plant hormones increased the rate of spikelet initiation and rate of apical meristem elongation, both of which are necessary for a higher final grain set per spike. [Figure 6] [Table 4]

Table 4. Increasing ratios of grain yield and number of grains per spike for the application of different plant hormones (3-indoleacetic acid [IAA], gibberellic acid [ $\left.\mathrm{GA}_{3}\right]$, or 6-benzylaminopurine [6-BAP]) in comparison with the controls in two dry-land wheat genotypes (Rijaw and Azar-2).

\begin{tabular}{ccccc}
\hline & \multicolumn{5}{c}{ First year } \\
\cline { 2 - 5 } Hormone & $\begin{array}{c}\text { Grain yield } \\
(\mathrm{kg} / \mathrm{ha})\end{array}$ & $\begin{array}{c}\text { Increasing ratio } \\
(\%)\end{array}$ & $\begin{array}{c}\text { Grains per } \\
\text { spike }\end{array}$ & $\begin{array}{c}\text { Increasing ratio } \\
(\%)\end{array}$ \\
\hline Control & $2105.1 \mathrm{c}$ & 0 & $32.7 \mathrm{~b}$ & 0 \\
IAA & $2491.1 \mathrm{~b}$ & 15.5 & $34.0 \mathrm{~b}$ & 3.8 \\
GA $_{3}$ & $2529.3 \mathrm{~b}$ & 16.8 & $38.6 \mathrm{ab}$ & 15.3 \\
6-BAP & $2930.1 \mathrm{a}$ & 28.1 & $42.2 \mathrm{a}$ & 22.5 \\
\hline LSD5\% & 295.23 & - & 6.54 & - \\
\hline & \multicolumn{4}{c}{ Second year } \\
Hormone & Grain yield & Increasing ratio & Grains per & Increasing ratio \\
& $(\mathrm{kg} / \mathrm{ha})$ & $(\%)$ & spike & $(\%)$ \\
\hline Control & $1797.8 \mathrm{c}$ & 0 & $33.6 \mathrm{~b}$ & 0 \\
IAA & $2298.8 \mathrm{~b}$ & 21.8 & $34.0 \mathrm{~b}$ & 1.2 \\
GA & $2399.3 \mathrm{ab}$ & 25.1 & $36.2 \mathrm{ab}$ & 7.2 \\
6-BAP & $2802.5 \mathrm{a}$ & 35.8 & $38.5 \mathrm{a}$ & 12.7 \\
\hline LSD5\% & 480.44 & - & 2.98 & - \\
\hline
\end{tabular}

Means with the same letter are not significantly different.

In both years of the present study (Figure 6a, b), the first two principal components accounted for $99.3 \%$ and $98.9 \%$ of total variation in the data set, respectively. The polygon for "which is best for what" indicates the best treatment combination (genotype $\times$ hormone) for each trait. In both panels of Figure 6, the biplot was divided into five sections. The peak treatment combination for each section was the one that gave the highest amount for the traits that fall within that section. The treatment combinations $\mathrm{Hr}_{4} \mathrm{G}_{1}$ (6-BAP and Rijaw) followed by $\mathrm{Hr}_{2} \mathrm{G}_{1}$ (IAA and Rijaw) were the best in terms of shoot apex length and rate of shoot apex elongation (based on days and GDDs). The treatment combination $\mathrm{Hr}_{3} \mathrm{G}_{1}\left(\mathrm{GA}_{3}\right.$ and Rijaw) was the top treatment combination in terms of spikelet number and rate of spikelet initiation (based on days and GDDs).

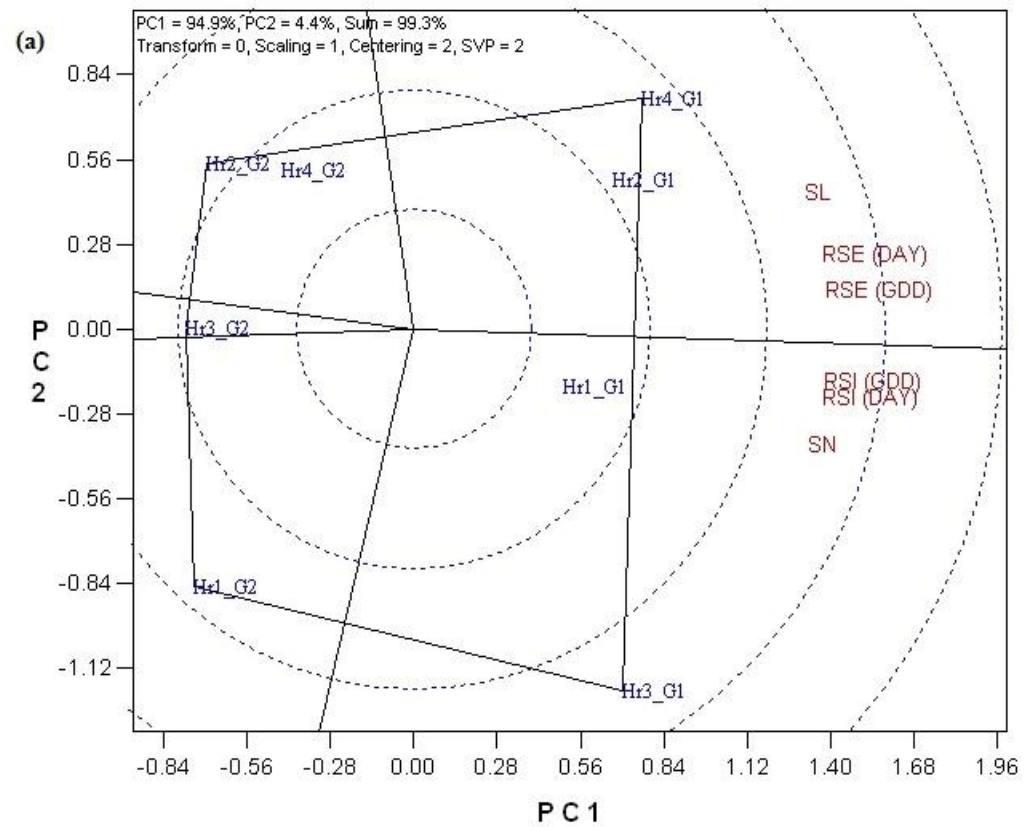




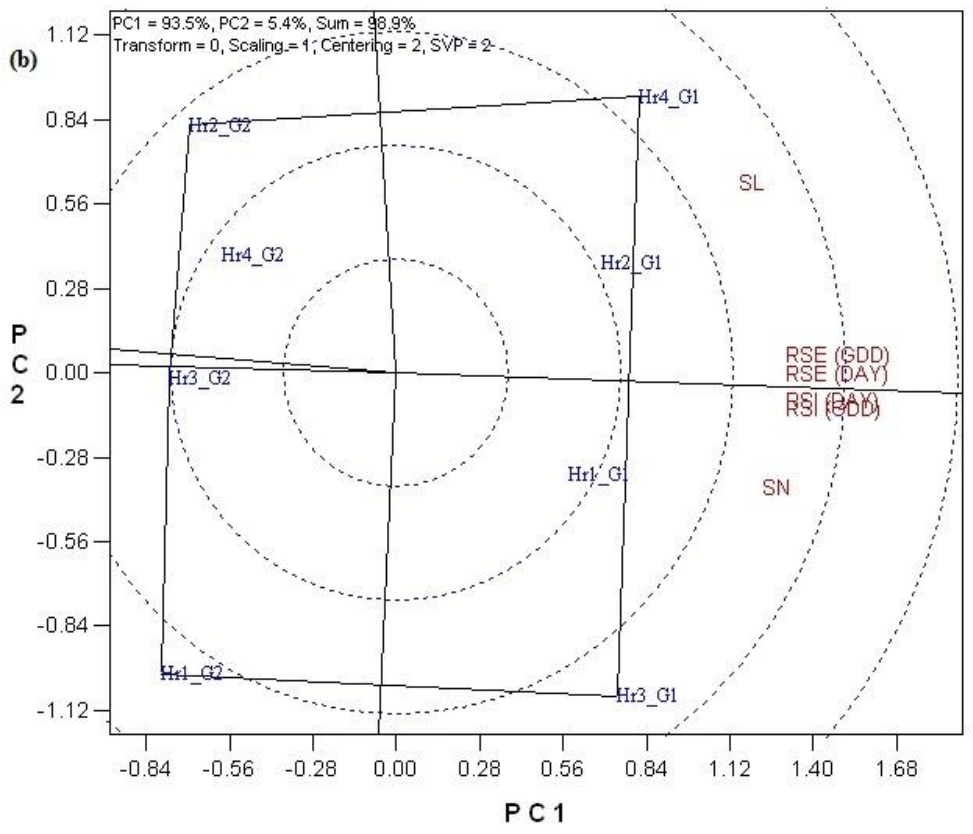

Figure 6. Polygon view of the principal component (PC) analysis biplot showing "which is best for what" for wheat shoot apex traits in the first year (a) and second year (b) of the experiment. RSE, rate of shoot apex elongation; SL, shoot apex length; RSI, rate of spikelet initiation; SN, spikelet number; $\mathrm{G}_{1}$, genotype 1 (Rijaw); $\mathrm{G}_{2}$,genotype 2 (Azar-2); $\mathrm{Hr}_{1}$, control; $\mathrm{Hr}_{2}, 3$-indoleacetic acid(IAA); $\mathrm{Hr}_{3}$, gibberellic acid $\left(\mathrm{GA}_{3}\right)$; $\mathrm{Hr}_{4}, 6$-benzylaminopurine (6-BAP)

In this experiment, a difference was found among the number of days from double ridge to terminal spikelet in each year based on days. The duration of this period was 14 and $16 \mathrm{~d}$ for Rijaw and Azar-2 genotypes in the first year, respectively, in comparison with 10 and $19 \mathrm{~d}$ in the second year (Table 1). The number of GDDs received by the plants was the same in both years $\left(68.5^{\circ} \mathrm{Cd}\right.$ and $67.4^{\circ} \mathrm{Cd}$ for the Rijaw genotype and $92^{\circ} \mathrm{Cd}$ and $89.8^{\circ} \mathrm{Cd}$ for the Azar-2 genotype) (Table 1).

\section{Conclusion}

In summary, the present study found that plant growth regulators could change the characteristics of the wheat apical meristem during the period from double ridge to terminal spikelet when grain set was being shaped. The present study showed also that hormone could affect a specific trait. Indeed, $\mathrm{GA}_{3}$ improved the spikelet initiation rate and the number of spikelets per shoot apex, whereas 6-BAP, which is a cytokinin, affected the length and elongation rate of the shoot apex.

As well, the duration of this critical stage was affected not only by genotype and the application of hormones but also by temperature. However, each wheat plant, depending on its genetic characteristics, had to receive a specified number of GDDs to complete this phase, and the transition time varied based on differences in daily temperature; therefore, the rates of spikelet initiation and apical meristem elongation were changed.

\section{Acknowledgments}

This study was supported by Razi University, Kermanshah, Iran, as a PhD thesis. The authors would like to thank all their colleagues (especially Saeid Sheikhehpour and Reza Amiri) in the Department of Agronomy and Plant Breeding, Campus of Agricultural and Natural Resources, Razi University, for their help and cooperation.

\section{References}

Acreche, M. M., \& Slafer, G. A. (2006). Grain weight response to increases in number of grains in wheat in a Mediterranean area. Field Crops Research, 98, 52-59. https://doi.org/10.1016/j.fcr.2005.12.005

Ahmadi, A., \& Baker, D. A. (1999). Effects of abscisic acid (ABA) on grain filling processes in wheat. Plant Growth Regulation, 28, 187-197. https://doi.org/10.1023/A:1006223925694

Amiri, R., Bahraminejad, S., Sasani, S., Jalali-Honarmand, S., \& Fakhri, R. (2015). Bread wheat genetic variation for grain's protein, iron and zinc concentrations as uptake by their genetic ability. European 
Journalof Agronomy, 67, 20-26. https://doi.org/10.1016/j.eja.2015.03.004

Bancal, P. (2009). Early development and enlargement of wheat floret primordia suggest a role of partitioning within spike to grain set. Field Crops Research, 110, 44-53. https://doi.org/10.1016/j.fcr.2008.06.014

Brancourt-Hulmel, M., Doussinault, G., Lecomte, C., Bérard, P., Le Buanec, B., \& Trottet, M. (2003). Genetic improvement of agronomic traits of winter wheat cultivars released in France from 1946 to 1992. Crop Science, 43, 37-45. https://doi.org/10.2135/cropsci2003.3700

Braun, H. J., Atlin, G., \& Payne, T. (2010). Multi-location testing as a tool to identify plant response to global climate change. In M. P. Reynolds (ed.), Climate Change and Crop Production. (pp. 115-138). Surrey, UK, CAB International. https://doi.org/10.1079/9781845936334.0115

Cakmak, I. (2008). Enrichment of cereal grains with zinc: Agronomic or genetic biofortification? Plant and Soil, 302, 1-17. https://doi.org/10.1007/s11104-007-9466-3

Darussalam, M., Cole, M. A., \& Patrick, J. W. (1998). Auxin control of photo-assimilate transport to and within developing grain of wheat. Australian Journal of Plant Physiology, 25, 69-78. https://doi.org/10.1071/PP97080

Duggan, B. L., Domitruk, D. R., \& Fowler, D. B. (2000). Yield component variation in winter wheat growth under drought stress. Canadian Journal of Plant Science, 80, 739-745. https://doi.org/10.4141/P00-006

Duggan, B. L., \& Fowler, D. B. (2006). Yield structure and kernel potential of winter wheat on the Canadian prairies. Crop Science, 46, 1479-1487. https://doi.org/10.2135/cropsci2005.06-0126

Evans, L. T. (1993). Crop Evolution, Adaptation and Yield.Cambridge, UK, Cambridge University Press.

González, F. G., Slafer, G. A., \& Miralles, D. J. (2003). Grain and floret number in response to photoperiod during stem elongation in fully and slightly vernalized wheats. Field Crops Research, 81, 17-27. https://doi.org/10.1016/S0378-4290(02)00195-8

Iran-Nejad, H., \& Shahbaziyan, N. (2005). Cereal Cultivation: Wheat. Vol.1. Tehran, Iran, Karenoo Publications.(In Persian.)

Itoh, H., Ueno, K., \& Yamazaki, K. (1998). Analysis of spike development of three spring wheat genotypes under various cultural conditions. Plant Production Science, 1, 258-263. https://doi.org/10.1626/pps.1.258

Kafi, M. (2001). Apex development of three wheat cultivars in the presence of salinity. Journal of Agriculture Science and Technology, 3, 1-8.

Kalantari, N., Ghaffarpour, M., HoushiarRad, A., Abdollahi, M., Kianfar, H., \& Bondarianzadeh, D. (2005). Iran national comprehensive study on household food consumption pattern and nutritional status 2001-2003. Tehran, Iran, Nutrition Research Department, National Nutrition and Food Technology Research Institute.

Kirby, E. J. M. (1974). Ear development in spring wheat. Journal of Agricultural Science (Cambridge), 82, 437-447. https://doi.org/10.1017/S0021859600051339

Lejeune, P., Prinsen, E., Van Onckelen, H., \& Bernier, G. (1998). Hormonal control of ear abortion in a stress-sensitive maize (Zea mays) inbred. Australian Journal of Plant Physiology, 25, 481-488. https://doi.org/10.1071/PP97154

Li, C., Cao, W., \& Dai, T. (1999). Dynamic characteristics of floret primordium development in wheat. Field Crops Research, 32, 98-100. https://doi.org/10.1016/S0378-4290(01)00144-7

Maas, E.V., \& Grieve, C.M. (1990). Spike and leaf development in salt-stressed wheat. Crop Science, 30, 1309-1313. https://doi.org/10.2135/cropsci1990.0011183X003000060031x

McMaster, G. S., Wilhelm, W. W., \& Morgan, J. A. (1992). Simulating winter wheat shoot apex phenology. Journal of Agricultural Science (Cambridge), 119, 1-12. https://doi.org/10.1017/S0021859600071483

Munns, R., \& Rawson, H. M. (1999). Effect of salinity on salt accumulation and reproductive development in the apical meristem of wheat and barley. Australian Journal of Plant Physiology, 26, 459-464. https://doi.org/10.1071/PP99049

Ober, E., \& Sharp, R. E. (1994). Proline accumulation in maize (Zea mays L.) primary roots at low water potentials: I. Requirement for increased levels of abscisic acid. Plant Physiology, 105, 981-987. https://doi.org/10.1104/pp.105.3.981 
Pask, A., Pietragalla, J., Mullan, D., \& Reynolds, M. (2012). PhysiologicalBreeding II: A Field Guide to Wheat Phenotyping. Mexico, DF, International Maize and Wheat Improvement Center (CIMMYT).

Pedró, A., Savin, R., \& Slafer, G. A. (2012). Crop productivity as related to single-plant traits at key phenologicalstages in durum wheat. Field Crops Research, 138, 42-51. https://doi.org/10.1016/j.fcr.2012.09.016

Reynolds, M., Bonnett, D., Chapman, S. C., Furbank, R. T., Manès, Y., Mather, D. E., \& Parry, M. A. J. (2011). Raising yield potential of wheat. I. Overview of a consortium approach and breeding strategies. Journal of Experimental Botany, 62, 439-452. https://doi.org/10.1093/jxb/erq311

Reynolds, M., Foulkes, J., Furbank, R., Griffiths, S., King, J., Murchie, E., ... Slafer, G. (2012). Achieving yield gains in wheat. Plant, Cell and Environment, 35, 1799-1823. https://doi.org/10.1111/j.1365-3040.2012.02588.x

Shekoofa, A., \& Emam, Y. (2008). Effects of nitrogen fertilization and plant growth regulators (PGRs) on yield of wheat (Triticumaestivum L.) cv. Shiraz. J. Agr. Sci. Tech, 10, 101-108.

Waddington, S. R., Cartwright, P. M., \& Wall, P. C. (1983). A quantitative scale of spike initial and pistil development in barley and wheat. Annals of Botany, 51, 119-130. https://doi.org/10.1093/oxfordjournals.aob.a086434

Wang, Z., Cao,W., Dai, T., \& Zhou, Q. (2001). Effects of exogenous hormones on floret development and grain set in wheat. Plant Growth Regulation, 35, 225-231. https://doi.org/10.1023/A:1014442006862

Wilkinson, S., \& Davies, W. J. (2002). ABA-based chemical signaling: The co-ordination of responses to stress in plants. Plant, Cell and Environment, 25, 195-210. https://doi.org/10.1046/j.0016-8025.2001.00824.x

Yang, J., Peng, S., Visperas, R. M., Sanico, A. L., Zhu, Q., \& Gu, S. (2000). Grain filling pattern and cytokinin content in the grains and roots of rice plants. Plant Growth Regulation, 30, 261-270. https://doi.org/10.1023/A:1006356125418

Yang, J., Zhang, J., Liu, K., Wang, Z., \& Liu, L. (2006). Abscisic acid and ethylene interact in wheat grains in response to soil drying during grain filling. New Phytologist, 171, 293-303. https://doi.org/10.1111/j.1469-8137.2006.01753.x

Yang, J., Zhang, J., Wang, Z., \& Zhu, Q. (2003a). Hormones in the grains in relation to sink strength and postanthesis development of spikelets in rice. Plant Growth Regulation, 41, 185-195.

https://doi.org/10.1023/B:GROW.0000007503.95391.38

Yang, J., Zhang, J., Wang, Z., Zhu, Q., \& Liu, L. (2002). Abscisic acid and cytokinins in the root exudates and leaves and their relationship to senescence and remobilization of carbon reserves in rice subjected to water stress during grain filling. Planta, 215, 645-652. https://doi.org/10.1007/s00425-002-0789-2

Yang, J. C., Zhang, J. H., Wang, Z. Q., Zhu, Q. S., \& Liu, L. J. (2003b). Involvement of abscisic acid and cytokinins in the senescence and remobilization of carbon reserves in wheat subjected to water stress during grain filling. Plant, Cell and Environment, 26, 1621-1631. https://doi.org/10.1046/j.1365-3040.2003.01081.x

Zadoks, J. C., Chang, T. T., \& Konzak, C. F. (1974). A decimal code for the growth stages of cereals. Weed Research, 14, 415-421. https://doi.org/10.1111/j.1365-3180.1974.tb01084.x

Zwart, S. J., \& Bastiaanssen, W. G. M. (2004). Review of measured crop water productivity values for irrigated wheat, rice, cotton and maize. Agricultural Water Management, 69, 115-133. https://doi.org/10.1016/j.agwat.2004.04.007

\section{Copyrights}

Copyright for this article is retained by the author(s), with first publication rights granted to the journal.

This is an open-access article distributed under the terms and conditions of the Creative Commons Attribution license (http://creativecommons.org/licenses/by/3.0/). 